\title{
BOMB-PULSE DATING OF HUMAN MATERIAL: MODELING THE INFLUENCE OF DIET
}

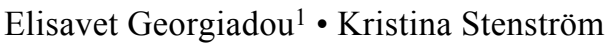 \\ Lund University, Department of Physics, Division of Nuclear Physics, Box 118, SE-221 00 Lund, Sweden.
}

\begin{abstract}
The atmospheric testing of nuclear weapons during the 1950 s and early 1960 s produced large amounts of radiocarbon. This ${ }^{14} \mathrm{C}$ bomb pulse provides useful age information in numerous scientific fields, e.g. in geosciences and environmental sciences. Bomb-pulse dating can also be used to date human material (e.g. in forensics and medical science). Bombpulse dating relies on precise measurements of the declining ${ }^{14} \mathrm{C}$ concentration in atmospheric carbon dioxide collected at clean-air sites. However, local variations in the ${ }^{14} \mathrm{C}$ specific activity of air and foodstuffs occur, which are caused by natural processes as well as by various human activities. As ${ }^{14} \mathrm{C}$ enters the human body mainly through the diet, variations of ${ }^{14} \mathrm{C}$ concentration in foodstuffs need to be considered. The marine component of the diet is believed to be of particular importance due to the non-equilibrium in ${ }^{14} \mathrm{C}$ specific activity between the atmosphere and aquatic reservoirs during the bomb pulse. This article reviews the ${ }^{14} \mathrm{C}$ concentration in marine foodstuffs during the bomb-pulse era, and models how the marine component in one's diet can affect the precision of bomb-pulse dating of human material.
\end{abstract}

\section{INTRODUCTION}

Atmospheric testing of nuclear weapons in the late 1950s and early 1960s had a profound impact on the levels of radiocarbon in the atmosphere. The tests approximately doubled the ${ }^{14} \mathrm{C}$ concentration in atmospheric $\mathrm{CO}_{2}$, and consequently in living matter, by the mid-1960s. In 1963, the majority of nuclear and many non-nuclear states signed the Limited Test Ban Treaty, pledging to refrain from testing nuclear weapons in the atmosphere, underwater, or in outer space. From the peak in 1963, the level of ${ }^{14} \mathrm{CO}_{2}$ has decreased exponentially with a mean life of about $16 \mathrm{yr}$ (Ubelaker and Buchholz 2005), not due to radioactive decay but due to mixing with large marine and terrestrial carbon reservoirs. This "bomb pulse" of excess ${ }^{14} \mathrm{C}$ was recorded in all parts of the living biosphere (Currie 2004). The ${ }^{14} \mathrm{C}$ bomb pulse can be used to obtain age information in geosciences, forensics, and environmental sciences (Harkness and Walton 1969, 1972; Wild et al. 2000; Goodsite et al. 2001). The technique has also been used for retrospective cell dating in humans, in order to provide fundamental insight about the rate of formation of new cells in the human body (Druffel and Mok 1983; Spalding et al. 2005a,b, 2008; Lynnerup et al. 2008).

Bomb-pulse dating of terrestrially living materials relies on precise measurements of the declining ${ }^{14} \mathrm{C}$ concentration in atmospheric carbon dioxide. The ${ }^{14} \mathrm{C}$ activity in atmospheric $\mathrm{CO}_{2}$ is mainly controlled by 4 major sources:

1. Natural ${ }^{14} \mathrm{C}$ produced by interactions of cosmic rays in the upper atmosphere;

2. Bomb ${ }^{14} \mathrm{C}$, originally introduced into the stratosphere in the Northern Hemisphere but subsequently stored in vast majority in the oceans and to some extent in the terrestrial biosphere;

3. ${ }^{14} \mathrm{C}$ released by the nuclear industry (such as nuclear power plants, reprocessing facilities for spent nuclear fuel, and ${ }^{14} \mathrm{C}$-using laboratories);

4. Fossil-fuel $\mathrm{CO}_{2}$, acting as a ${ }^{14} \mathrm{C}$-free dilutant-also referred to as the Suess effect.

A number of post-bomb atmospheric ${ }^{14} \mathrm{C}$ records are available taking into account that post-bomb atmospheric ${ }^{14} \mathrm{C}$ data varies somewhat regionally (Reimer et al. 2004). These data are collected at clean-air sites, far from the whereabouts of most humans, thus minimizing the effect on the data sets from local releases of ${ }^{14} \mathrm{C}$ from nuclear installations and from dilution of fossil-fuel $\mathrm{CO}_{2}$. However,

\footnotetext{
${ }^{1}$ Corresponding author: elisavet.georgiadou@nuclear.lu.se.

(C) 2010 by the Arizona Board of Regents on behalf of the University of Arizona Proceedings of the 20th International Radiocarbon Conference, edited by A J T Jull RADIOCARBON, Vol 52, Nr 2-3, 2010, p 800-807
} 
as pointed out by Reimer et al. (2004), there are also local variations, and hence a local atmospheric ${ }^{14} \mathrm{C}$ data set would be ideal for calibration of a post-bomb ${ }^{14} \mathrm{C}$ measurement of e.g. terrestrial plants. However, when dating human material, other factors also need to be considered.

The transfer of bomb ${ }^{14} \mathrm{C}$ into the human body and the resulting ${ }^{14} \mathrm{C}$ specific activity in human tissues mainly depend on the following 3 factors, according to Nydal et al. (1971):

1. The time between the photosynthesis in vegetal food and its consumption;

2. The diet, particularly its vegetal food content;

3. The residence time of the carbon in different parts of human tissue.

However, most human diets consist not only of terrestrially grown vegetal food and meat products (the latter generally have a longer delay time of ${ }^{14} \mathrm{C}$ from the atmosphere to human consumption than that of vegetal foods, according to Broecker et al. 1959). Fish and seafood are usually also part of the diet, and the importance of this marine source can vary significantly regionally as well as individually.

During the bomb pulse, the ${ }^{14} \mathrm{C}$ specific activity in marine organisms differed significantly from that of terrestrial foods due to the delay time for bomb ${ }^{14} \mathrm{C}$ to enter the oceans and due to the non-equilibrium in ${ }^{14} \mathrm{C}$ specific activity between the atmosphere and aquatic reservoirs. Post-bomb marine data sets exist and have been derived from coral, coralline sponges, fish otoliths, and shell chronologies (Reimer et al. 2004). These data sets show much higher regional variation than the atmospheric ones. This fact, in combination with interindividual amounts of dietary components of marine origin, may lead to variations in ${ }^{14} \mathrm{C}$ specific activity for different individuals. This paper addresses how the marine component of the diet can affect the precision of bomb-pulse dating of human material, like blood and hair samples, by estimating the mean $\Delta^{14} \mathrm{C}$ values for local diets at 5 different regions around the globe.

\section{MATERIALS AND METHODS}

Post-bomb $\Delta{ }^{14} \mathrm{C}$ data for marine organisms $\left(\Delta^{14} \mathrm{C}_{\text {marine }}\right)$ were collected from the literature. Five different sites distributed worldwide were used to demonstrate regional variations ${ }^{2}{ }^{14} \mathrm{C}$ in marine organisms: Barents Sea (Kalish et al. 2001) $\left(71^{\circ} \mathrm{N}, 40^{\circ} \mathrm{E}\right.$, part of the Arctic Ocean, north of Norway); Georges Bank (Weidman and Jones 1993$)\left(41^{\circ} \mathrm{N}\right.$, east of Massachusetts state, USA); New Zealand (Kalish 1993) $\left(39^{\circ} \mathrm{S}, 179^{\circ} \mathrm{E}\right.$, Wellington and east coast); south and southeast Australia (Kalish 1995, Kalish et al. 1997) (35 $\left.{ }^{\circ} \mathrm{S}, 139^{\circ} \mathrm{E}\right)$; and United Kingdom (Cook et al. 1998; Campana et al. 2006) (NE Atlantic, NW England coast). Parts of the UK data are from the vicinity of the nuclear fuel reprocessing plant in Sellafield, to demonstrate the potential influence on the ${ }^{14} \mathrm{C}$ levels in marine diets originating from the nuclear power industry wastes into the sea.

In the case of the Barents Sea data, Kalish et al. (2001) used Arcto-Norwegian cod otoliths to create the post-bomb time series (1950-1990) for the marine environment. In the Georges Bank case, Weidman and Jones (1993) used data derived from growth bands of a 54-yr-old mollusk specimen (Bilvania, Arctica islandica) shell, collected live from Georges Bank to produce the local marine $\Delta^{14} \mathrm{C}$ data set. Otolith data from squirefish (Pagrus auratus) were collected by Kalish (1993) off the east coast of North Island, New Zealand, for the corresponding calculation of the $\Delta^{14} \mathrm{C}$ values. For the $\mathrm{S}$ and SE Australia study case, fish and otolith ${ }^{14} \mathrm{C}$ data obtained from blue grenadier (Macruronus novaezelandiae) as well as from redfish (Centroberyx affinis) and used for the local marine $\Delta^{14} \mathrm{C}$ data set (Kalish 1995; Kalish et al. 1997). The marine $\Delta^{14} \mathrm{C}$ data for the UK west coast originate from dogfish spines (Squalus acanthias) sampled in the NE Atlantic (Campana et al. 2006). 
In the particular case of Sellafield (UK), ${ }^{14} \mathrm{C}$ activity values of samples from fish and other sea creatures (mussels, flatfish, roundfish, and crustacea), collected by Cook et al. (1998), were used. $\Delta^{14} \mathrm{C}$ was calculated following the formula of Stuiver and Polach (1977) and by taking under consideration that $\mathrm{A}_{\mathrm{SN}}$ is the normalized sample activity and $\mathrm{A}_{\mathrm{ABS}}$, which is the absolute international standard activity, is $13.56 \mathrm{dpm} / \mathrm{g} \mathrm{C}$ (Karlén et al. 1964), equaling $226 \mathrm{~Bq} / \mathrm{kg} \mathrm{C}$.

$$
\Delta^{14} \mathrm{C}=\left[\frac{\mathrm{A}_{\mathrm{SN}}}{\mathrm{A}_{\mathrm{ABS}}}-1\right] \cdot 1000 \%
$$

The atmospheric data $\Delta{ }^{14} \mathrm{C}_{\text {atm }}$ used for each region were obtained from the Hua and Barbetti (2004) data set. Particularly for the Barents Sea and the UK cases, data for the Northern Hemisphere (NH) zone 1 were used for years before 1970, while for the years after 1970 average values from the locations above $40^{\circ} \mathrm{N}$ were used. In the Georges Bank case, New York area data were used for years before 1970 while for years after 1970 average values from locations below $40^{\circ} \mathrm{N}$ were used. For New Zealand, data from Wellington $\left(41^{\circ} \mathrm{S}, 174^{\circ} \mathrm{E}\right)$ were used for $1955-59,1973,1978-79,1984$, 1987-88 and Southern Hemisphere (SH) averages were used for 1993-97. For S/SE Australia, data from Armidale $\left(30^{\circ} \mathrm{S} 152^{\circ} \mathrm{E}\right)$ were used except for period $1978-97$ where $\mathrm{SH}$ averages were used.

The local human diet's ${ }^{14} \mathrm{C}$ concentration for the different regions was estimated as:

$$
\Delta \Delta^{14} \mathrm{C}_{\text {diet }}=X_{\text {marine carbon }} \cdot \Delta{ }^{14} \mathrm{C}_{\text {marine }}+\left(1-X_{\text {marine carbon }}\right) \cdot \Delta{ }^{14} \mathrm{C}_{\text {atm }}
$$

where $X_{\text {marine carbon }}$ is the fraction of local protein diet derived from seafood, according to the FAO (2008) and $\Delta^{14} C_{\text {marine }}$ is the local post-bomb marine data set. The dietary fraction (1- $\left.X_{\text {marine carbon }}\right)$ represents the rest of the protein in the human diet, originating from meat and vegetables, etc. For this fraction, the local atmospheric data set $\left(\Delta^{14} \mathrm{C}_{\text {atm }}\right)$ was used, assuming that foodstuffs of terrestrial origin are in equilibrium with the atmosphere of the region. Lag times of ${ }^{14} \mathrm{C}$ entering the terrestrial proteins have not been considered in the calculations.

\section{RESULTS AND DISCUSSION}

Table 1 shows the average daily intake of marine foods according to the $\mathrm{FAO}$ at the various sites. Figure 1a shows marine post-bomb data $\left(\Delta^{14} \mathrm{C}_{\text {marine }}\right)$, atmospheric data $\left(\Delta^{14} \mathrm{C}_{\text {atm }}\right)$, and the dietary values $\left(\Delta^{14} \mathrm{C}_{\text {diet }}\right)$ for the Barents Sea, calculated using the equations above and the values in Table 1. Since the average marine protein dietary fraction is relatively low $(8 \%)$, the diet ${ }^{14} \mathrm{C}$ concentrations are rather close to the local atmospheric ${ }^{14} \mathrm{C}$ concentration. Figure $1 \mathrm{~b}$ shows an estimation of the difference in age between the diet curve and the atmospheric curve, i.e. the approximate error in the age determination that the marine food component can introduce compared to using the atmospheric calibration curve. Some $8 \%$ of fish from the Barents Sea in the human diet can alter the date determination in a range from about -2.4 to $1.4 \mathrm{yr}$ maximum compared with the age, coming from the respective atmospheric data. However, an individual consuming twice the average (16\% of fish) would give an approximate age alteration range from -2.7 to $2.7 \mathrm{yr}$.

Table 1 Fish food consumption in the different study cases (FAO).

\begin{tabular}{ll}
\hline Location & $\begin{array}{l}\text { Fraction of dietary protein fish and seafood } \\
\text { consumption, } X_{\text {marine carbon }} \text { (FAO 2008) }\end{array}$ \\
\hline Barents Sea (Russia, Finland average) & 0.08 (time period: $1990-92,2003-05)$ \\
Georges Bank (USA) & 0.04 (time period: 1990-97) \\
New Zealand & 0.05 (time period: $1990-92)$ \\
S-SE Australia & 0.04 (time period: $1990-97)$ \\
United Kingdom & 0.05 (time period: $1990-2005)$ \\
\hline
\end{tabular}




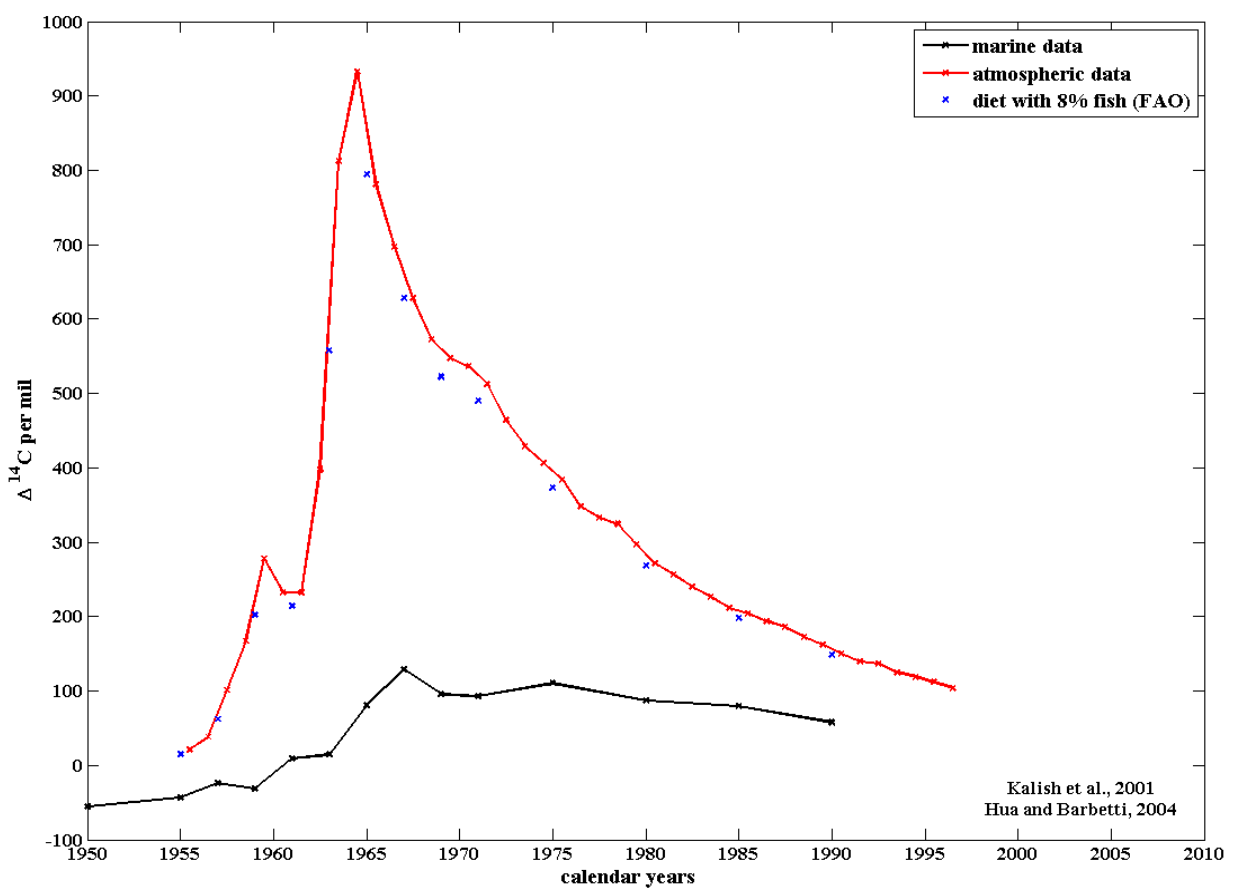

Figure 1a Atmospheric, marine, and dietary curve of ${ }^{14} \mathrm{C}$ data for the Barents Sea

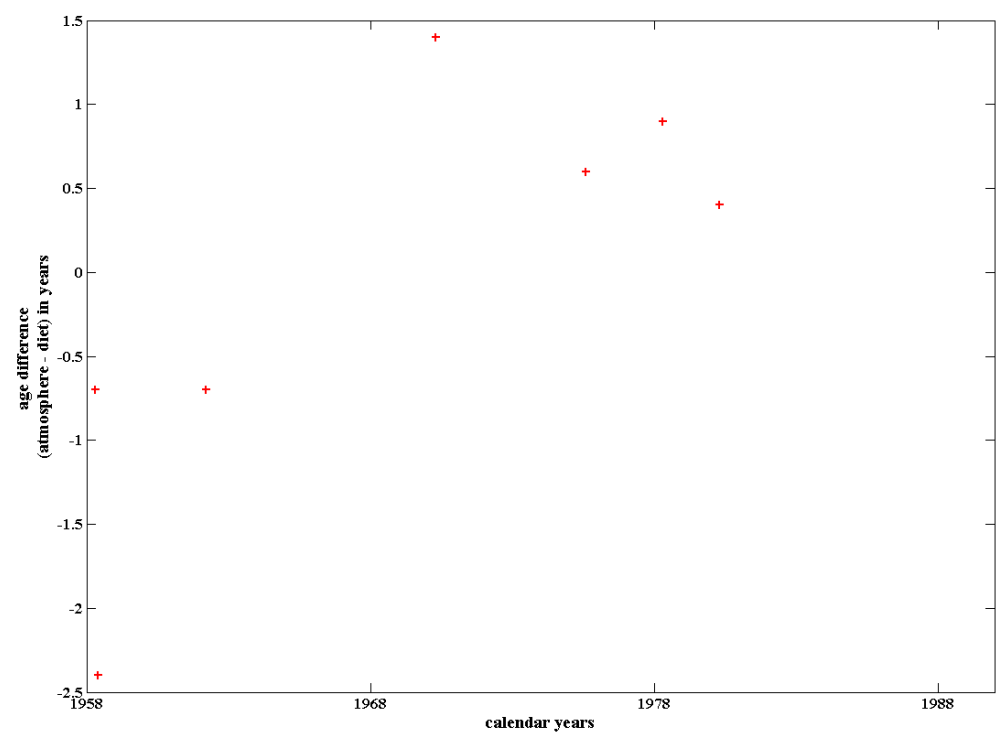

Figure $1 \mathrm{~b}$ Age alteration between atmosphere and diet in the Barents Sea region, with $8 \%$ fish in the diet.

Figures 2-4 show the results of the dietary modeling for Georges Bank, New Zealand, and Australia. These have a lower average consumption of fish than in the Barents Sea, and the age alteration range arising in these cases is given in the Table 2, which also includes the age alteration that results from a diet with fish from Sellafield. 


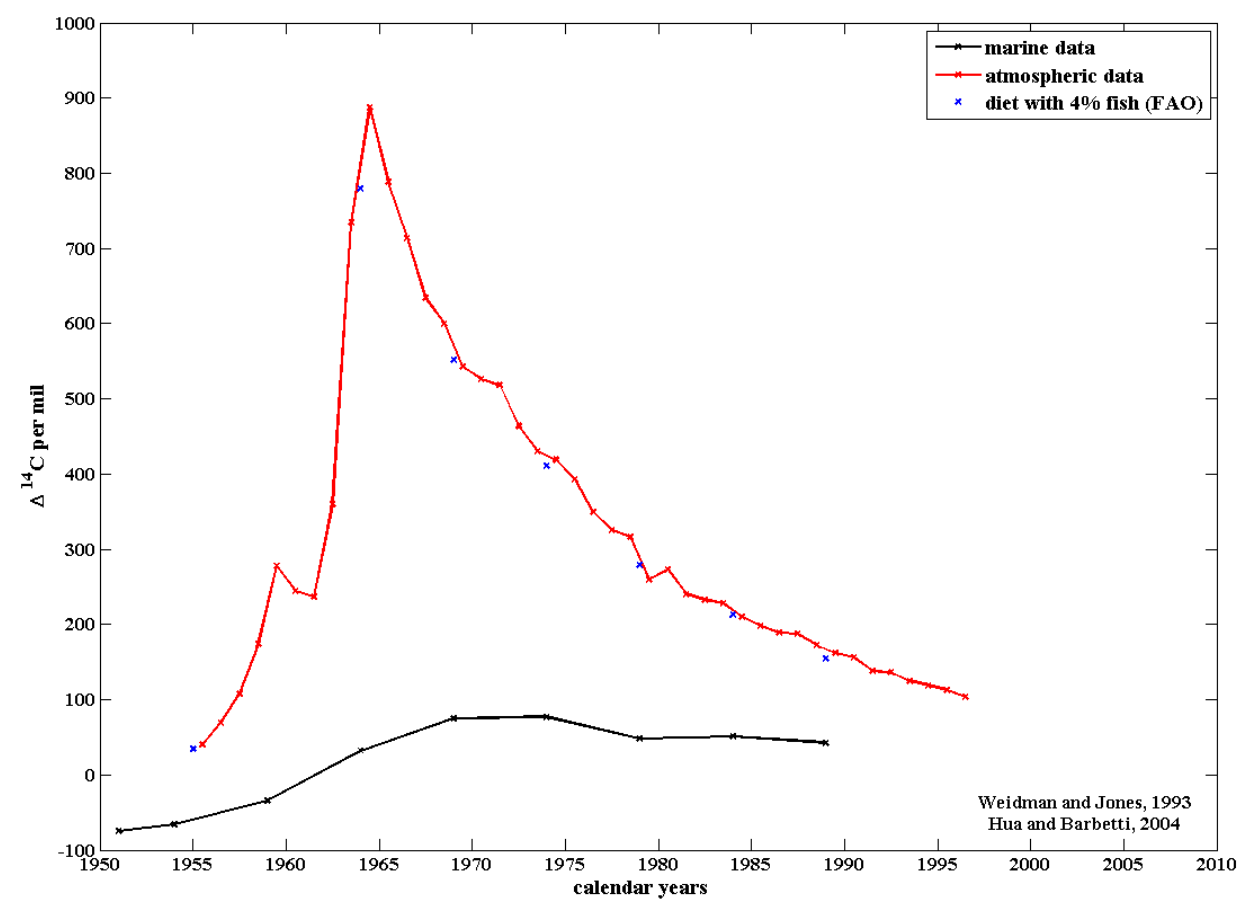

Figure 2 Atmospheric, marine and dietary curve of ${ }^{14} \mathrm{C}$ data for Georges Bank

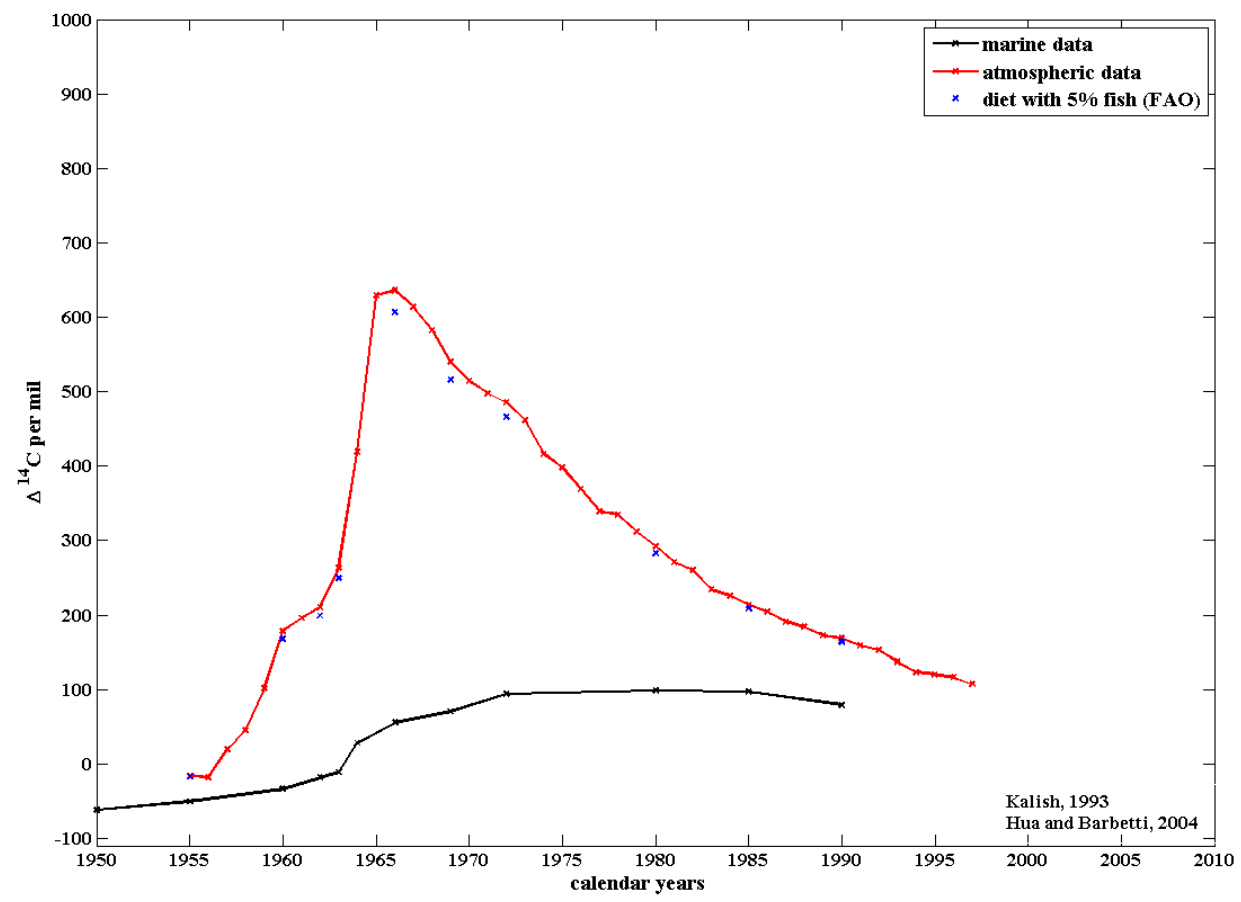

Figure 3 Atmospheric, marine and dietary curve of ${ }^{14} \mathrm{C}$ data for New Zealand 


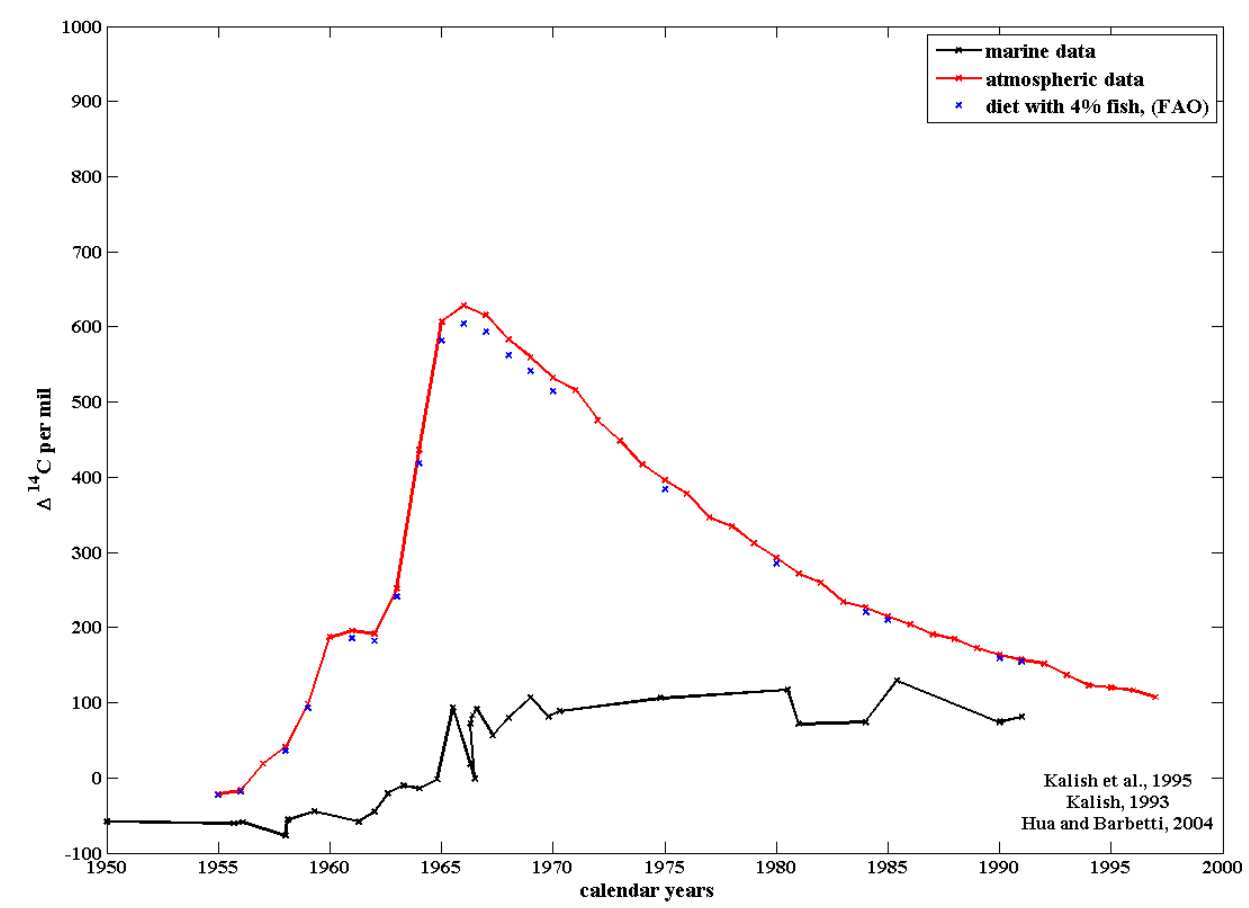

Figure 4 Atmospheric, marine, and dietary curve of ${ }^{14} \mathrm{C}$ data for $\mathrm{S}$ and SE Australia

Table 2 Age alteration range (atmospheric age-diet age) in years.

\begin{tabular}{ll}
\hline Region & Age alteration range \\
\hline Barents Sea & $-2.4-1.4$ \\
USA (Georges Bank) & $-0.1-1$ \\
New Zealand & $-1.1-0.9$ \\
S/SE Australia & $-2.2-1.1$ \\
UK (Sellafield), 1995 & -26.3 \\
\hline
\end{tabular}

Figure 5 shows the outcome of modeling the data from the UK. $\Delta^{14} \mathrm{C}$ values corresponding to a protein diet with 5\% fish and seafoods from Sellafield in $1995\left(\Delta^{14} \mathrm{C}_{\text {diet }}=566 \%\right)$ were calculated using the mean ${ }^{14} \mathrm{C}$ activity of all marine specimens collected at the Sellafield site $(2305 \mathrm{~Bq} / \mathrm{kg} \mathrm{C}$, corresponding to $\Delta^{14} \mathrm{C}_{\text {marine }}=9200 \%$ ), as reported by Cook et al. (1998) (mussels $=3305 \mathrm{~Bq} / \mathrm{kg} \mathrm{C}$, flatfish $=2694 \mathrm{~Bq} / \mathrm{kg} \mathrm{C}$, roundfish $=2543 \mathrm{~Bq} / \mathrm{kg} \mathrm{C}$, and crustacean $=679 \mathrm{~Bq} / \mathrm{kg} \mathrm{C}$ ). The significantly enhanced ${ }^{14} \mathrm{C}$ concentrations in the diet would lead to alteration of the year determination of $26.3 \mathrm{yr}$ compared to the atmospheric data (Table 2).

Based on the modeling results of the diets, it can be concluded that the ${ }^{14} \mathrm{C}$ concentration in one's diet can indeed affect the accuracy of bomb-pulse dating on human samples. In our calculations, we have not taken into account that some of the food might be stored for prolonged times prior to consumption, which can lead to further age prediction alterations compared to the predicted age according to the atmospheric ${ }^{14} \mathrm{C}$ content. To further evaluate the precision of bomb-pulse dating of human material, we plan to retrieve and analyze human blood samples, collected during the bomb pulse and stored at a biobank. 


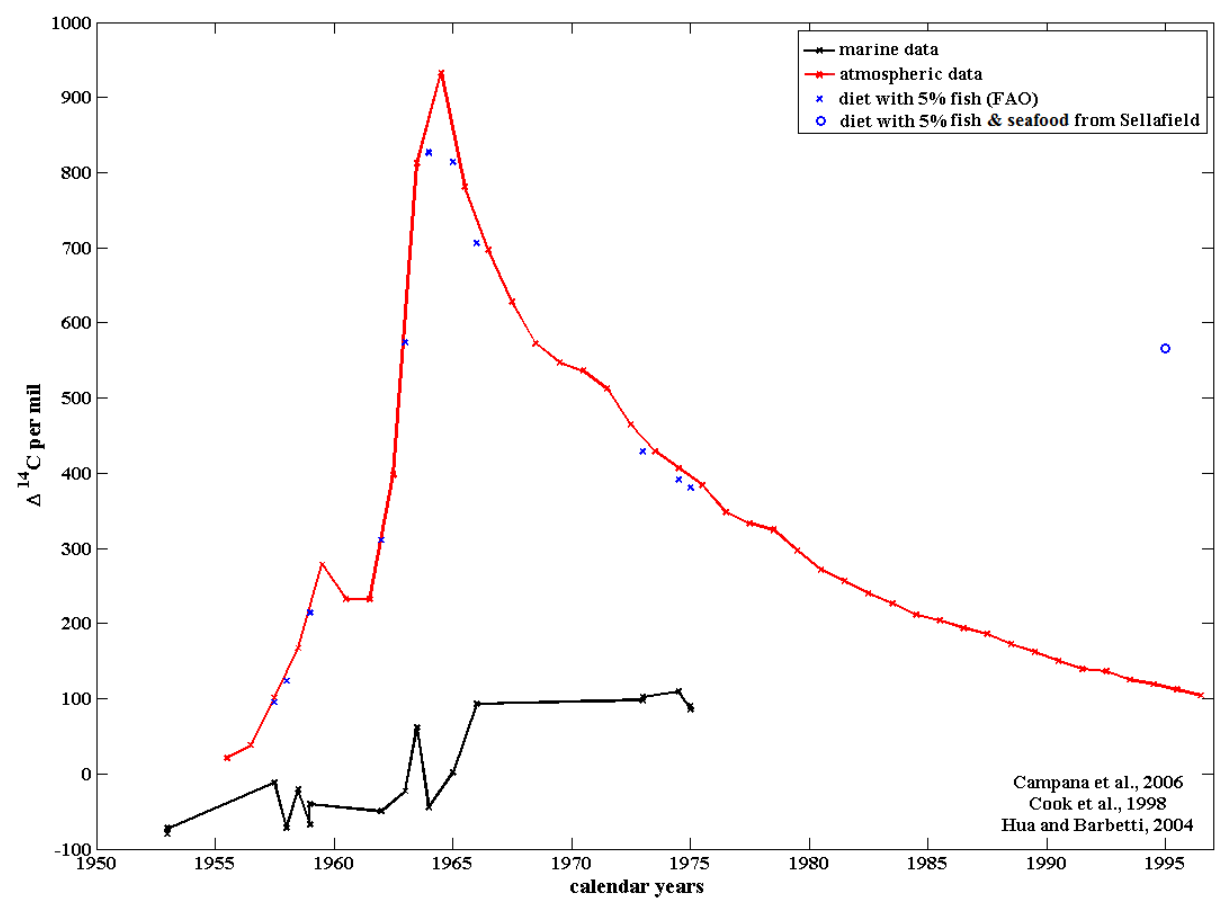

Figure 5 Atmospheric, marine, and dietary curve of ${ }^{14} \mathrm{C}$ data for the UK

\section{CONCLUSIONS}

This study shows that a human diet containing a normal fraction of food of marine origin has the potential of influencing bomb-pulse dating by up to a few years, compared to the atmospheric data. For example, $8 \%$ of fish from the Barents Sea in the human diet can alter the age determination by around $-2.4 \mathrm{yr}$ maximum. For an individual consuming twice the average of fish $(16 \%)$, the age alteration ranges from about -2.7 to $2.7 \mathrm{yr}$. The dietary modeling study also shows that the considerably enhanced ${ }^{14} \mathrm{C}$ concentrations, which can be found in fish near nuclear installations (such as the Sellafield nuclear fuel reprocessing plant), can lead to an alteration of age determination of several tens of years compared to the atmospheric data. Thus, for high-precision bomb-pulse dating of human material, it is necessary to consider possible variations of ${ }^{14} \mathrm{C}$-specific activities in the diet.

\section{REFERENCES}

Broecker WS, Schulert A, Olson EA. 1959. Bomb carbon-14 in human beings. Science 130(3371):331-2.

Campana SE, Jones C, McFarlane GA, Myklevoll S. 2006. Bomb dating and age validation using the spines of spiny dogfish (Squalus acanthias). Environmental Biology of Fishes 77(3-4):327-36.

Cook GT, MacKenzie AB, Naysmith P, Anderson R. 1998. Natural and anthropogenic ${ }^{14} \mathrm{C}$ in the UK coastal marine environment. Journal of Environmental Radioactivity 40(1):89-111.

Currie LA. 2004. The remarkable metrological history of radiocarbon dating [II]. Journal of Research of the $\mathrm{Na}$ tional Institute of Standards and Technology 109(2): 185-217.
Druffel EM, Mok HYI. 1983. The history of human gallstones: application of the post-bomb radiocarbon signal. Radiocarbon 25(2):629-36.

Food and Agriculture Organization of the United Nations (FAO). 2008. Food consumption pattern of main food groups [WWW document]. http://www.fao.org/ fileadmin/templates/ess/documents/food_security statistics/DietFoodGroupsProtein_en.xls. Accessed March 2009.

Goodsite ME, Rom W, Heinemeier J, Lange T, Ooi S, Appleby PG, Shotky W, van der Knaap WO, Lohse C, Hansen TS. 2001. High-resolution AMS ${ }^{14} \mathrm{C}$ dating of post-bomb peat archives of atmospheric pollutants. Radiocarbon 43(2B):495-515. 
Harkness DD, Walton A. 1969. Carbon-14 in the biosphere and humans. Nature 223(5212):1216-8.

Harkness DD, Walton A. 1972. Further investigations of the transfer of bomb ${ }^{14} \mathrm{C}$ to man. Nature $240(5379)$ : 302-3.

Hua Q, Barbetti M. 2004. Review of tropospheric bomb ${ }^{14} \mathrm{C}$ data for carbon cycle modeling and age calibration purposes. Radiocarbon 46(3):1273-98.

Kalish JM. 1993. Pre- and post-bomb radiocarbon in fish otoliths. Earth and Planetary Science Letters 114(4): 549-54.

Kalish JM. 1995. Application of the bomb radiocarbon chronometer to the validation of redfish Centroberyx affinis age. Canadian Journal of Aquatic Sciences 52: 1399-405.

Kalish JM, Johnston JM, Smith DC, Morison AK, Robertson SG. 1997. Use of the bomb radiocarbon chronometer for age validation in the blue grenadier Macruronus novaezelandiae. Marine Biology 128(4): 557-63.

Kalish JM, Nydal R, Nedreaas KH, Burr GS, Eine GL. 2001. A time history of pre- and post- bomb radiocarbon in the Barents Sea derived from Arcto-Norwegian cod otoliths. Radiocarbon 43(2B):843-55.

Karlén I, Olsson IU, Kållberg P, Kilicci S. 1964. Absolute determination of the activity of two $\mathrm{C}^{14}$ dating standards. Arkiv för Geofysik 4(22):465-71.

Lynnerup N, Kjeldesen H, Heegard S, Jacobsen C, Heinemeier J. 2008. Radiocarbon dating of the human eye lens crystallines reveal proteins without carbon turnover throughout life. PloS ONE 3(1): e1529, doi: 10.1371/journal.pone.0001529.
Nydal R, Lövseth K, Syrstad O. 1971. Bomb ${ }^{14} \mathrm{C}$ in the human population. Nature 232(5310):418-21.

Reimer PJ, Brown TA, Reimer RW. 2004. Discussion: reporting and calibration of post-bomb ${ }^{14} \mathrm{C}$ data. Radiocarbon 46(3):1299-304.

Spalding KL, Bhardwaj RD, Buchholz BA, Druid H, Frisén J. 2005a. Retrospective birth dating of cells in humans. Cell 122(1):133-43.

Spalding KL, Buchholz BA, Bergman L-E, Druid H, Frisén J. 2005b. Age written in teeth by nuclear tests. Nature 437(7057):333-4.

Spalding KL, Arner E, Westermark PO, Bernard S, Buchholz BA, Bergmann O, Blomqvist L, Hoffstedt J, Näslund E, Britton T, Concha H, Hassan M, Rydén M, Freisén J, Arner P. 2008. Dynamics of fat cell turnover in humans. Nature 453(7196):783-7.

Stuiver M, Polach HA. 1977. Discussion: reporting of ${ }^{14} \mathrm{C}$ data. Radiocarbon 19(3):355-63.

Ubelaker DH, Buchholz BA. 2006. Complexities in the use of bomb-curve radiocarbon to determine time since death of human skeletal remains. Forensic Science Communication 8(10). https://e-reportsext.llnl.gov/pdf/319544.pdf. Accessed March 2009.

Weidman CR, Jones GA. 1993. A shell-derived time history of bomb ${ }^{14} \mathrm{C}$ on Georges Bank and its Labrador Sea implications. Journal of Geophysical Research 98(C8):14,577-88.

Wild E, Sarlamovsky KA, Golser R, Kutschera W, Priller A, Puchegger S, Rom W, Steier P, Vycudilik W. 2000. ${ }^{14} \mathrm{C}$ dating with the bomb peak: an application to forensic medicine. Nuclear Instruments and Methods in Physics Research B 172(1-4):944-50. 